\title{
Ngā Mahi Ora ā Rēhia (Diabetes prevention and intervention programme)
}

\section{Ngā Kākano Foundation}

Ngā Mahi Ora ā Rēhia is a programme designed and delivered by Ngā Kākano Foundation, a Māori Health Provider based in Te Puke. Tribal pride and identity is central to Ngā Kākano Foundation's philosophical approach to health. The founder of Ngā Kākano, Piatarihi Kihirini believed that if the tamariki and rangatahi were nurtured in their culture they would grow and flourish. This ideological stance is reflected in the name of the Foundation, Ngā Kākano which links the organisation back to the tribe's origins: Ngā kākano i ruia mai i a Rangiātea - the seed sown in Rangiātea. The vision of the organisation is contained in the purpose statement: Oranga tangata, Oranga whānau, Oranga hapū, Oranga iwi. The focus on family and tribal wellbeing gives an indication of the inseparable relationship between the organisation and the iwi (Tapuika). This is further reinforced with Ngā Kākano Foundation's philosophical statement, which adopts a Tapuika tribal whakatauki that reflects the organisation's determination to achieve health and wellbeing within the community.

Ahakoa teitei te maunga ka taea te piki

Ahakoa pēhea nunui o te ngaru o te moana

Ka pakaru i te ihu iti o te waka.

No matter how high the mountain we can scale it

No matter how high the waves of the sea

The prow of the little canoe will break 


\section{Nā TE KOATA (Tapuika)}

Ngā Kākano Foundation health services are delivered within a holistic cultural framework which emphasises the relationship between cultural wellness as the foundation for health and wellbeing. The approach is all encompassing taking into account the inextricable relationship between the people and the environment through whakapapa. Staff related to the earth, Papatuānuku through whakapapa that contends that wellness/unwellness of people is reflected in the wellness/unwellness of the environment. The environment in te takapū o Tapuika (tribal estate), particularly the waterways, are mostly contaminated and this arguably correlates with the health status of the people. This approach is replicated in numerous studies on indigenous health and the environment (Levin 1988, LaDuke 1992 Pholeros, Rainow, Torzillo P 1993, Carson B, Dunbar T, Chenhall et.al 2007, WHO 2009).

\section{Ngā Mahi Ora ā Rēhia}

Manaaki Tangata is the wrap around service for all Ngā Kākano programmes and provides support services including; transport, housing, budgetary advice etc. Ngā Mahi ora ā Rèhia, the diabetic intervention programme engage the client and their whānau in a programme that uses whakapapa to identify those whānau with evidence of intergenerational susceptibility to the disease. The programme in terms of health outcome gains relies on the entire whānau engaging in healthy lifestyle changes (embedded in Māori holistic health models). The objectives are twofold, firstly to help the client with diabetes manage the disease and secondly to prevent the next generation of the whānau succumbing to the inevitable (diabetes disease).

The philosophy underpinning the programme is contained in the name, Ngā Mahi Ora ā Rēhia. In Māori traditions Rēhia is the atua of recreation, pleasure and enjoyment. This strategy is inspired by the whakataukì, 'Kia kawea tātou e te 
Rèhia' (Rēhia charms us). By placing the programme under the auspices of this atua Ngā Kākano accentuates and promotes the programme as positive and enjoyable - but also multifaceted. Although Ngā Mahi Ora a Rèhia is the pragmatic application of tikanga $\mathrm{i}$ to involve whānau in healthy lifestyle choices, it is also linked to physical, social, mental, environmental and spiritual dimensions of wellbeing.

The following description is taken from a Ngā Mahi ā Rēhia performing arts programme usually associated with Rēhia (www.tki.org.nz/r/arts/ngatoi/nga_mahi/index_e.php). To Māori cultural, holistic principles of wellness are applied to all spheres of life - even music and dance.

Tukuna mai ngā taonga o reira hei whakapakari oranga pūmau, hei kawe whakaaturanga o ngā kitenga, o ngā rongo, o ngā taha rerehua, me te whakatinana i ngā tikanga, ngā moemoeā, ngā uara me ngā tūmanako, i runga i te tika me te pono.

The word 'ora' in the Ngā Kākano programme is significant because it reinforces emphatically the Māori wellness approach to health (in contrast with conventional medicine which focuses on disease). This wellness approach harnesses all facets of the Ngā Mahi Ora a Rēhia as a learning experience to achieve health and wellness to address unwellness (diabetes). The Māori definition of this programme is comprehensive and embodies cultural heritage, learning and wellness as key components of the programme.

Physical activity was always an integral part of holistic wellness for Māori. 'Traditional games and activities required coordination, stamina and fitness. Not only were they ways of having fun; they were also important in preparation for warfare, hunting, gardening, skills and leadership development, strengthening tribal development, and the transfer of cultural knowledge' (Thomas and Dyall 1999 p.120).

The exercise and healthy eating components of Ngā Mahi Ora à Rēhia accentuate the 'fun' aspect of Māori social 
practices as a tool to encourage whānau participation. Family involvement is a feature of the programme that is recognised (across cultures) as a useful tool in the management of chronic diseases (Kaugars, Klinnery, \& Bender, 2004; Tarnovetskaia \& Cook 2008; Worthington 2008). Ngā Mahi Ora ā Rēhia takes this principle further because whānau involvement is also linked to whakapapa as a clinical tool for diabetes early intervention. Enrolment on the program is based on whether the participants have a strong whānau whakapapa (family history) of diabetes (as well to those already diagnosed with diabetes type 2 diabetes).

Grounded in the community's tribal knowledge base, recreational (physical exercise) activities centre on, waiata, mahi $\bar{a}$ ringa and other mahi $\bar{a}$ toi associated with Rēhia. Similarly, healthy eating is shaped by the relationship with Papatuānuku to promote gardening and the consumption of natural, rather than processed food. The kai prepared and served with tūroro and their whānau teaches participants to prepare healthy food - that is also very palatable. The influence of Rēhia emphasises te reka, the sweetness of the food.

\section{Clinical component of Te Mahi Ora a Rēhia}

Enrolment with the program requires a cultural assessment to be undertaken in collaboration with the diabetes community health coordinator. The objective is the development of a comprehensive care plan. Marae, community halls and tribal office boardrooms are considered the most appropriate venues to encourage whānau/family for support.

A local registered nurse is engaged on a monthly fee for service (maximum of 2 hours per month) basis to undertake monthly wellness checks as part of the program. Checks include weight, blood pressure and capillary blood testing 'finger prick' meters and strips of those participants diagnosed 
with diabetes or where signs of pre diabetes was evident in individual participants.

The program nurse and diabetes community worker document any concerns and actions to be taken in the individual participant's care plan e.g. elevated blood sugar reading and referral was made to their local GP. The diabetes community worker regularly follow ups participants to monitor participant progress against their care plan.

\section{Clinical Outcomes}

Ngā Kākano Foundation negotiated changes to the government monitoring and reporting model to better document tūroro (client) health gains. Consequently they are able to effectively track the progress of client's management of disease to maintain an acceptable level of wellness. The shift in focus is indicative of a radically different approach to reporting. Current health monitoring frameworks focus on the prevalence of illness to ascertain Māori health status. The effective management of disease to achieve the highest level of wellness possible typifies the Māori approach to health.

Most significantly in relation to measurable short term outcomes, $\mathrm{HbA} 1 \mathrm{c}$ readings $<8$ are the standard measurement (for health gains amongst participants on the programme). DHB Reporting and Monitoring records provides evidence that the majority of participants engaged in the programme are meeting the minimal readings $\mathrm{HbAlc}<8$ standard. Considering that the majority of participants when first enrolled on the programmer record $\mathrm{HbA} 1 \mathrm{c}$ readings in double digits this is a significant improvement in terms of health gains. This approach differs from the conventional approach to diabetes which is normally disease focussed. 


\section{Evidence based key outcomes}

- $\quad 63 \%$ of enrolled participants diagnosed with diabetes were found to have either improved control or maintained control of their condition. Key contributing factors to their improvement was support of whānau in terms of diet and exercise, follow up of Coordinators after each program session, competition with other participants

- $16 \%$ of enrolled participants diagnosed with diabetes were found to have poor control. Contributing factors were erratic dietary habits and non-compliance with medication

- $79 \%$ of enrolled participants who did not have diabetes but had a strong whānau whakapapa of diabetes recorded improvements in BP readings and weight

- $13 \%$ of enrolled participants who did not have diabetes but had a strong whānau whakapapa of diabetes remained at a consistent $\mathrm{BP}$ reading and weight

- $\quad 8 \%$ of enrolled participants who did not have diabetes but had a strong whānau whakapapa of diabetes were referred to their GP for further follow up

- More GP involvement in the different areas and the offer of a nurse to assist with program in the Murupara region

- Request by two additional providers in the Eastern Bay of Plenty Poutiri Network to join in the delivery of the program to Maori in their area.

\section{Government Reporting and Monitoring Constraints}

The challenges that this programme presents relates primarily to the inability of government monitoring reporting systems to capture the kaupapa Māori component of the programme. This omission is considerable given the infrastructure of Ngā Mahi 
Ora $\bar{a}$ Rēhia is shaped by tikanga. Furthermore, the epistemological differences between Māori thought and government reporting requirements generate problems that impact negatively on the programme.

Ngā Kākano Foundation found (in extending the programme to other sites in the Bay of Plenty) that government monitoring and reporting systems could jeopardise the programme expansion. Culturally based health promotion/early intervention programmes are high maintenance and require significant social, personal and financial investment. As expected issues arise around capacity issues which in turn result in increased programme costs. For example, in order to meet DHB funded targets, one delivery site decided to significantly increase enrolments (well in excess of contracted volumes). The rationale for increased numbers of enrolled participants is designed solely to meet DHB targets. This strategy brings no added value to the programme. Furthermore, the inflexibility of government health funding systems precludes consideration of simple solutions to support, rather than obstruct programme delivery.

The underlying issue is the absence of government performance indicator measurements to measure holistic approaches to wellness. Global or mainstream indicators are still valued important in measuring the health of all the population, including Māori. They are however limited in their capacity to capture the complete picture of Māori health according to Māori concepts of health and wellbeing (Ratima, Edwards et al 2005; Ministry of Health 2006; Durie, Fitzgerald et al 2002; Durie 2006).

Currently there is no universal Māori-specific health indicator sets. There is a mass of information in existence that can be drawn upon for universal measures that incorporate ethnicity. However, there is a limitation on the range of Māori-specific information available that is collected regularly, if at all. The information that is collated is not all contained in one place and comes from a range of sources. 
With no suitable Māori health performance indicators to measure the cultural and holistic components of Ngā Mahi Ora $\overline{\mathrm{a}}$ Rēhia, the programme relies solely on government monitoring systems to measure performance. The negotiation of a more flexible measurement of client health gains has resulted in Ngā Kākano Foundation recording evidence based improvements in the health status of participating clients.

\section{Future Development}

The success of this stream of service delivery has resulted in Ngā Kākano Foundation extending the service to other sites in the Bay of Plenty. In 2007 the Bay of Plenty District Health Board renewed the Ngā Mahi Ora a Rēhia contract and increased the program frequency to fortnightly sessions with an additional two sites in the Eastern Bay of Plenty thus increasing the annual contracted participant numbers. A corresponding increase in budget was also negotiated and agreed. In June 2008 the Bay of Plenty District Health Board commissioned a Scoping Report of the Ngā Mahi Ora service. The Report recommended that the service be further extended to an additional five sites in the Bay of Plenty (Moko Business Associates, 2008 Diabetes Scoping Report, p 31).

The philosophical difference between primary (clinical) health disease management approaches for high need populations compared to the public health population based approach is well documented (Ministry of Health 2003 Public Health in a Primary Health Care Setting, Social Policy Journal of New Zealand 2005 Implementing the Primary Health Care Strategy). Ngā Kākano Foundation provides evidence of improved health gains for their clients. According to government policy documents this is also the main objective of the government's Māori health strategy. Therefore it is reasonable to expect more flexibility from the government funding models so that programmes (such as Ngā Mahi Ora ā 
Rèhia) that actually do achieve better health outcomes for Māori are not compromised.

\section{References}

Carson B, Dunbar T, Chenhall RD, Bailie R, eds. (2007) Social determinants of Indigenous health. Crows Nest, NSW: Allen and Unwin

Durie, M. (2006). Measuring Maori Wellbeing. Paper presented at New Zealand Treasury Guest Lecture Series on 1 August 2006, Wellington.

Durie, M., Fitzgerald, E., Kingi, T.K., McKinley, S., and Stevenson B. (2002) Maori Specific Outcomes and Indicators: A report prepared for Te Puni Kokiri, the Ministry of Maori Development, Wellington, Te Putahi a Toi, School of Maori Studies, Massey University.

Kaugars, A., Klinnery, M. \& Bender, B. (2004). Family Influences on Paediatric Asthma. In Journal of Paediatric Psychology. Issue 29: pp. $474-491$.

LaDuke, W. Indigenous Environmental Perspectives: A North American Primer. In the Akwekon Journal,_Summer 1992: 63.

Levin S., Akwesasne Environment: The Limits of Science. In Northeast Indian Quarterly, Fall1988: 30-34.

Ministry of Health (2003). Public Health in a Primary Health Care Setting, Wellington: Ministry of Health.

Ministry of Health (2006). The Mãori Health Action Plan Whakatātaka Tuarua. Wellington: Ministry of Health.

Moko Business Associates (2008). Diabetes Scoping Report. A paper commissioned for Ngā Kākano Foundation.

Pholeros P, Rainow S, Torzillo P (1993) Housing for health: towards a healthy living environment for Aboriginal Australia. Newport Beach, NSW: HealthHabitat

Ratima, M., Edwards, W. and Crengle, S. (2005). Māori Health Indicators: A Background Paper for the Project 'Action Oriented Indicators for Health and Health Systems Development for Indigenous Peoples in Canada, Australia and New Zealand.' Auckland: Auckland University.

Tarnovetskaia A. \& Cook, L. (2008). The Impact of Cultural Values, Family Involvement and Health Services on Mental Health and Mental Illness. In the Canadian Journal of Family and Youth, 1(2), pp. 113-126.

Thomas, D.R. \& Dyall, L. (1999). Culture, Ethnicity, and Sport Management: a New Zealand Perspective. In Sport Management Review, 2: pp. 115-132. 
World Health Organization (2009) Environmental health. Retrieved16 July 2012 from: http://www.who.int/topics/environmental_health/en/

Worthington, B. (2008). Diabetes Management In Young People Family Matters

In Social Work Today Vol. 8 No. 5 P. 18 September/October 2008 Issue 